\title{
Establishment of A Reproductive Health Care Carader in Integrated Service Post (Posyandu) Youth Village Penyengat Olak Muaro Jambi District
}

\author{
Ruwayda ${ }^{1}$, Dewi Nopiska Lilis ${ }^{2}$, M.Dody Izhar ${ }^{3}$ \\ Jurusan Kebidanan Poltekkes Kemenkes Jambi, Jambi, Indonesia \\ FKIK Univ Jambi, Jambi, Indonesia \\ Corresponding Author : ruwayda@poltekkesjambi.ac.id
}

\begin{abstract}
At the posyandu for youth, the IEC includes providing information about adolescent reproductive organs, puberty, the process of pregnancy, menstruation, family planning, sexually transmitted diseases, gender and maturity of marriage age. HIV / AIDS includes providing information about transmission, prevention and symptoms. Based on data from the Health Office of Muaro Jambi Regency, in the area of Puskesmas Penyengat Olak, the target number of adolescents aged 10-18 years is 1,959 males and 1,903 females. This large number is an opportunity to form a youth posyandu. Community service activities will be carried out in Penyengat Olak Village, Muaro Jambi Regency. This community service aims to increase the capacity of youth as cadres of the village post at Penyengat Olak district. Muaro Jambi. Target adolescents aged 10-18 years who are in the area of olak stinger health centers. There are activities in the form of advocacy to puskesmas and the community in establishing youth Posyandu, recruiting cadres and holding youth Posyandu cadres training, implementing youth Posyandu formation in stinging olak villages. The output of community service activities is the formation of cadres to care for reproductive health in pilot youth Posyandu for the work area of the Pengegat Olak Community Health Center in Muaro Jambi Regency. olak stinger. Through this training activity it is very important to increase the coverage of adolescent reproductive health services and it is hoped that the support of the puskesmas and village officials is expected.
\end{abstract}

Keywords: Training, Youth Cadre, Reproductive Health

\section{INTRODUCTION}

Health is a human right (UUD 1945, Article 28H paragraph 1 and Law No. 36 of 2009 concerning health) and at the same time as an investment, so it needs to be strived for, fought for and improved by every individual and by all components of the nation, so that people can enjoy a healthy life, and in the end can realize the optimal level of public health. Health Law Number 36 of 2009 Articles 17 and 18 states that the Government is responsible for the availability of access to information, education and health service facilities as high as possible. The government is also responsible for empowering and encouraging the active role of the community in all forms of health efforts. This needs to be done because health is not the responsibility of the government alone, but is a joint responsibility of the government and the community, including the private sector

Adolescence is a transitional period between childhood and adulthood, where a growth spurt occurs, secondary sex characteristics arise, fertility is achieved and psychological and cognitive changes occur. Adolescents are still not able to master and function optimally their physical and psychological functions. However, what needs to be emphasized here is that the adolescent phase is a developmental phase that is in a period of great potential, both in terms of cognitive, emotional and physical aspects (Dieny, 2014).

One of the problems that can arise as a result of this behavior is reproductive health problems. Reproductive health is often misunderstood narrowly as just sexual intercourse, so many parents feel that this topic of conversation is inappropriate to discuss with teenagers. In fact, reproductive health is a state of physical, mental, and social health that is very important for adolescents to understand, so that it does not only discuss sexual relations (Putri, 2018). 
The World Health Organization (WHO) has compiled, adolescent reproductive health problems that occur throughout the world, which can be used as a comparison for the same problem in Indonesia, or the assumption of events in Indonesia if data is not yet available. Indicators for reproductive health problems are presented in this section. Information on reproductive health problems, besides being important for health service providers, decision makers, is also important for education and program organizers for adolescents, in order to help reduce adolescent reproductive health problems (Suryaningsih, 2018).

Based on the results of the 2015 School-Based Health Survey in Indonesia, it can be seen a picture of health risk factors in students aged 12-18 years (junior and high school) nationally. As many as $41.8 \%$ of men and $4.1 \%$ of women admitted to having smoked, $32.82 \%$ of them smoked for the first time at the age of 13 years. The same data also shows that $14.4 \%$ of men and $5.6 \%$ of women have ever consumed alcohol, then $2.6 \%$ of men have consumed drugs. Another risk factor description is sexual behavior where $8.26 \%$ male students and $4.17 \%$ female students aged 12-18 years have had sexual intercourse. Premarital sexual behavior certainly has a broad impact on adolescents, especially related to the transmission of infectious diseases and unwanted pregnancies and abortions (Kemenkes RI, 2018).

Pregnancy in adolescents not only affects the physical, mental and social conditions of adolescents, but can also increase the risk of infant and toddler mortality, as shown by the 2012 SDK where pregnancy and childbirth in mothers under the age of 20 have contributed to the high Neonatal Mortality Rate (34). /1000 live births), Postnatal Mortality Rate (16/1000 live births), Infant Mortality Rate (50/1000 live births). The quarterly report of the Directorate General of Disease Control and Environmental Health (Ditjen P2PL) from 1987 to March 2017 shows that the high incidence of AIDS in the 20-29 year age group indicates that this group was first exposed to HIV at a young age (Kemenkes RI, 2018).

This situation is certainly dangerous, the absence of accurate information causes adolescents to seek and obtain information about reproductive health from unreliable sources, such as their friends or from pornographic media. As a result, their perception of sex and reproductive health becomes wrong and unhealthy. Puberty makes adolescents aware of their potential and become more expressive in exploring their sexual organs and behavior. The wrong perception of reproductive health and sexuality can be carried into their sexual behavior (Putri, 2018).

The complexity of health problems in adolescents, of course, requires a comprehensive and integrated treatment that involves all elements from across programs and related sectors. The health policy related to adolescent health services as referred to in the Minister of Health Regulation Number 25 of 2014 is intended so that every child has the ability to behave in a clean and healthy life, have healthy life skills and good social skills so that they can learn, grow and develop harmoniously and optimally to become human resources. quality (Kemenkes RI, 2018).

According to Notoatmodjo (2010) media is one of the factors that can affect one's knowledge. People who are able to use the media well will find it easier to obtain the information they need. Research conducted by Maarif (2017) on the effect of reproductive health education with the snake and ladder game media on the knowledge and attitudes of junior high school students in Selo Boyolali showed that there was a difference in the average score of knowledge and attitudes in the experimental group compared to the control group.

Putro's research (2009) on alternative development of adolescent reproductive health models is by using reproductive health models and channeling the potential of adolescents by involving all components of society in order to meet the needs of adolescent reproductive health so that it is expected to provide positive benefits for adolescent development.

In the Muaro Jambi district, there is no youth posyandu, which has just been pioneered, namely the youth posyandu in Penyengat Olak village. Based on data obtained from the Penyengat Olak Health Center, Muaro Jambi Regency, it is known that the number of adolescents aged 10-18 years is 1,959 males and 1,903 females (Muaro Jambi District Health Office, 2018). This number is very large considering the many problems that arise in the area, namely the high number of early marriages in the village of Penyengat Olak, the number of teenage pregnancies $<18$ years old. 3 people (\%). Cases of reproductive tract infections and 
sexually transmitted infections are known that the number of infected adolescents has not been reported.

The complexity of health problems in adolescents certainly requires a comprehensive and integrated treatment that involves all elements from across programs and related sectors. The Ministry of Health has developed the Youth Care Health Program (PKPR) at the Puskesmas, with a comprehensive service package for adolescent health including IEC, counseling, peer counselor development, clinical/medical services and referrals including community empowerment. However, in-building services provided by health personnel still have limited number of facilities and infrastructure and barriers related to access due to diverse geography, this requires efforts to empower the community in the form of independent community participation in promotive and preventive efforts such as activities such as posyandu (Ministry of Health RI), 2018).

Youth posyandu cadres are part of youth health cadres. Those who can be selected to become posyandu cadres are teenagers aged 10-18 years, creative, innovative and committed, willing to voluntarily become cadres and domiciled in the youth posyandu area. Youth posyandu cadres who are no longer in their teens can continue to join youth posyandu activities. Youth posyandu cadres can also join other youth organizations such as saka bakti husada / other saka in the scout movement, youth organizations or other organizations (Kemenkes RI, 2018).

Based on data from the Health Office of Muaro Jambi Regency, in the Penyengat Olak Health Center area, the target number of adolescents aged 10-18 years is 1,959 males and 1,903 females. This large number is an opportunity to form youth posyandu and youth posyandu cadres who care about adolescent reproductive health (Dinkes Ma.Jambi, 2019).

Jambi Health Polytechnic (Poltekkes) as a higher education institution that has the task of carrying out the Tri Dharma of Higher Education: Teaching education, research, and community service trying to realize community service activities as a means or place to practice the theory obtained on campus directly and in real life in the community, so that Poltekkes can contribute to helping the community in growing, fostering, and developing community participation in the field of health development, especially maternal and child health so that people are aware of their health and can overcome their own health problems.

\section{METHOD}

The implementation of community service activities in the form of capacity building activities for youth as posyandu cadres in the Penyengat Olak Health Center, Kab. Muaro Jambi.

The establishment of the youth posyandu was carried out in coordination with the Puskesmas Penyengat Olak, especially the person in charge of youth health services. The stages are:

1. Planning And Preparation Stage

a. Conduct initial survey and Advocacy for Community Leaders and Heads of Health Centers

b. Conducting data collection on target adolescents 10-18 years in the area of the Penyengat Olak Health Center

c. Recruiting cadres aged 10-18 years who meet the requirements to be trained to become posyandu cadres

2. Implementation Stage

a. Conducted capacity building for youth posyandu cadres (increasing knowledge and skills) in Penyengat Olak village in collaboration with resource persons from the district health office of Muaro Jambi.

b. In collaboration with the village head and the head of the Penyengat Olak Health Center to conduct the inauguration of posyandu cadres and the issuance of an Inauguration Decree

c. Collaborate with the coordinator of the Health Center Health Center in including PKPR activities with the PHBS and Germas programs.

3. Monitoring And Evaluation Stage

a. Conduct periodic monitoring of activities at the youth Posyandu

b. Carry out an evaluation of Youth Capacity Building activities as Posyandu Cadres in Penyengat Olak Village, Muaro Jambi Regency. 


\section{RESULTS AND DISCUSSION}

Community Service activities were carried out for 3 times, namely on 29 July, 19 and 26 September. The location of the activity is in the hall of the Penyengat Olak Health Center, Muaro Jambi Regency. This activity was attended by 20 teenagers. The average age of the teenagers who are the target of the activity is 17.63 years old, with a minimum age of 15 years and a maximum age of 24 years. The average age of the participants can be seen in table 1.

Table 1. The average age of the participants

\begin{tabular}{llll}
\hline Variable & & Age (year) & \\
\hline Age & Mean & Minimum & Maximum \\
\hline $15-24$ & 17,63 & 15 & 24 \\
\hline
\end{tabular}

The implementation of mentoring activities for the formation of youth posyandu went well, enthusiastic residents and community leaders as well as the head of the puskesmas in supporting this activity. The village head plans to hold a meeting with the hamlet head and RT to record the number of youth 10-19 years old in the village area of Penyengat Olak, and will include it in the Village Fund budget.

Achieved outputs:

1. The first stage has been carried out, namely advocacy to community leaders, village heads in planning the formation of a youth posyandu starting from the definition of posyandu, the benefits of posyandu and the capacity of the large number of teenagers in the village of Penyengat Olak.

2. The second stage is a meeting with the village management, by presenting the head of the Puskesmas Penyengat Olak and the person in charge of the reproductive health program at the Puskesmas, village midwives who are directly involved in the technical implementation of the activities.

3. The third stage, together with the village midwife, selects 5 active and voluntary youth as youth posyandu cadres per village.

4. In the fourth stage, 60 youth posyandu cadres have been trained.

\section{CONCLUSION}

The conclusions of the results of community service activities are:

1. The implementation of the activities for the formation of the youth posyandu has been carried out smoothly and has received a good response from the village head, community leaders, youth leaders and the head of the Penyengat Olak Health Center

2. After the establishment of the posyandu, 5 youths were selected to be trained to become posyandu cadres.

3. 60 youth cadres who have been trained come from several villages in the working area of PKM Penyengat Olak

4. The head of the puskesmas and the person in charge of the health care center of the Penyengat Olak Health Center will facilitate the youth in cadre training

5. The village head will prepare posyandu facilities and infrastructure such as scales, height measuring instruments, LILA tape, register books and other supporting facilities, and plan to prepare cadre transportation operational funds in the Village Fund Budget (ADD) of Penyengat Olak village. 


\section{REFERENCES}

BPS dan ORC Macro, 2012, Survei Demografi dan Kesehatan Indonesia. Calverton, Maryland, USA ORC Macro

Badan Pusat Statistik, 2015 Data Kesehatan Indonesia, Jakarta

Dinas Kesehatan Kab Muaro Jambi, 2019, Data Sasaran Dinas Kesehatan Kab. Muaro Jambi. Dinkes Muaro Jambi

Puskesmas Aur Duri, 2019, Data Kunjungan Remaja, Puskesmas Penyengat Olak Kab Muaro Jambi

Kementerian Kesehatan RI, 2009. Sistem Kesehatan Nasional , Jakarta Kemenkes RI ,2015. Petunjuk Teknis Penyelenggaraan Posyandu Remaja, Jakarta Kemenkes RI 2015. Survei Kesehatan Berbasis Sekolah, Jakarta Kemenkes RI

Laili, A, Riyanti, E \& Syamsulhuda, 2019. Faktor-faktor yang berhubungan dengan Praktik Pemanfaatan Pelayanan Kesehatan Peduli Remaja (PKPR) oleh Remaja di wilayah kerja Puskesmass Bandarharjo Kota Semarang. Jurnal Kesehatan Masyarakat Undip Vol 7 No1 Januari 2019. http://ejournal3.undip.ac.id.index.php/jkm

Lestari, I., Hartati, E., Galuh, M., \& Kunci, K. (n.d.). DI WILAYAH TLOGOSARI KULON RW 16 KOTA SEMARANG

Nursalam, 2016, Metode Penelitian Keperawatan, Salemba Medika Jakarta

Roestiyah, 2010, Strategi Belajar Mengajar, Jakarta Rineka Cipta

Suprijanto, 2007, Pendekatan Orang Dewasa dari Teori Hingga Aplikasi,Jakarta Bumi Aksara

Trianto 2007, Model-Model Pembelajaran Inovatif Berorientasi Konstruktif, Jakarta Penerbit Prestasi Pusktaka

Triono, 2007, Mendesain Model Pembelajaran Inovatif Progresif, Jakarta PT Kencana

Wibowo, M., Gustina, E., \& Hastuti, S. K. W. (2020). THE EFFORTS TO INCREASE KNOWLEDGE AS PEER EDUCATORS IN THE YOUTH Jurnal Pengabdian Dan Pemberdayaan Masyarakat, 4(2), 187-193 


\section{APPENDIX}

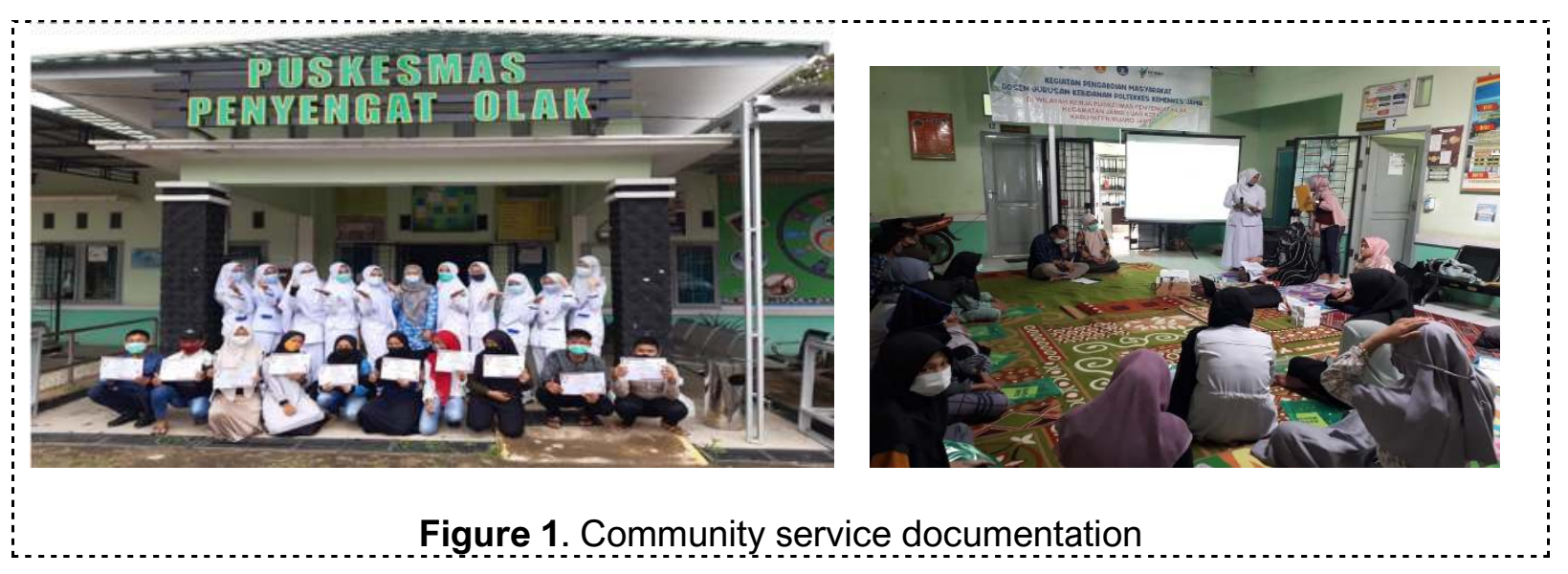

